\title{
Review \\ Minireview: Parabens Exposure and Breast Cancer
}

\author{
Emily Hager ${ }^{1}$, Jiangang Chen ${ }^{2, *}$ and Ling Zhao ${ }^{1, *}$ (I) \\ 1 Department of Nutrition, University of Tennessee, Knoxville, TN 37996, USA; emily.nicole.hager@gmail.com \\ 2 Department of Public Health, University of Tennessee, Knoxville, TN 37996, USA \\ * Correspondence: jchen38@utk.edu (J.C.); lzhao7@utk.edu (L.Z.); \\ Tel.: +1-865-974-8487 (J.C.); +1-865-974-1833 (L.Z.)
}

check for

updates

Citation: Hager, E.; Chen, J.; Zhao, L. Minireview: Parabens Exposure and Breast Cancer. Int. J. Environ. Res.

Public Health 2022, 19, 1873.

https://doi.org/10.3390/

ijerph19031873

Academic Editors: Zhaomin Dong, Ying Wang, Xiaomin Li and Paul B. Tchounwou

Received: 1 January 2022

Accepted: 3 February 2022

Published: 8 February 2022

Publisher's Note: MDPI stays neutral with regard to jurisdictional claims in published maps and institutional affiliations.

Copyright: (C) 2022 by the authors. Licensee MDPI, Basel, Switzerland. This article is an open access article distributed under the terms and conditions of the Creative Commons Attribution (CC BY) license (https:// creativecommons.org/licenses/by/ $4.0 /)$.

\begin{abstract}
There is increasing recognition that environmental exposure to chemicals, such as endocrinedisruptive chemicals (EDCs), contributes to the development of breast cancer. Parabens are a group of EDCs commonly found in personal care products, foods, and pharmaceuticals. Systemic exposure to parabens has been confirmed by the ubiquitous detection of parabens in human blood and urine samples. Although evidence from in vivo and epidemiological studies linking parabens exposure to breast cancer is limited, the current evidence suggests that parabens may negatively interfere with some endocrine and intracrine targets relevant to breast carcinogenesis. So far, most studies have focused on a single paraben's effects and the direct modulating effects on estrogen receptors or the androgen receptor in vitro. Recent studies have revealed that parabens can modulate local estrogen-converting enzymes, $17 \beta$-hydroxysteroid dehydrogenase 1 and 2 and increase local estrogen levels. Also, parabens can crosstalk with the human epidermal growth factor receptor 2 (HER2) pathway and work with ER signaling to increase pro-oncogenic c-Myc expression in ER+/HER2+ breast cancer cells. Future studies investigating paraben mixtures and their crosstalk with other EDCs or signaling pathways both in vitro and in vivo in the context of breast cancer development are warranted.
\end{abstract}

Keywords: paraben; breast cancer; endocrine-disruptive chemicals

\section{Introduction}

Breast cancer remains the second leading cause of cancer deaths (only second to lung cancer) in women in the US in 2021. It is estimated that more than 40,000 women will die from breast cancer in 2021 [1]. The average risk of a woman developing breast cancer at some time in her life is about $13 \%$ [1].

The risk factors for breast cancer have been identified and are grouped into nonmodifiable (familial and hereditary) factors and modifiable (environmental) factors [2]. The familial risk factors include a family history of breast cancer, other breast diseases, or high breast density. Women with inherited mutations, specifically in BRCA1 and BRCA2, may have a higher breast cancer risk. The genetic risks of breast cancer only account for approximately $5-10 \%$ of breast cancers, whereas $90 \%$ of breast cancer occurrence is thought to be environment-related [2]. The most commonly known modifiable risk factors for breast cancer are obesity, sedentary lifestyle, having a first child after 30, post-menopausal hormone and oral contraceptives use, and xenoestrogen exposure [3].

A growing body of evidence from animal and human studies links exposure to environmental chemicals with increased risks of developing breast cancer. Among them are endocrine-disrupting chemicals (EDCs) [4-6]. EDCs are exogenous chemicals that can interfere with endogenous hormone action with key characteristics, including activating or antagonizing hormone receptors or altering receptor expression and downstream signaling events in the sensitive cells [7]. The most common examples of EDCs are dioxins, polychlorinated biphenyls, bisphenol A, and parabens found in products such as plastics, detergents, foods, toys, cosmetics, or pharmaceuticals [8]. Parabens are 4-hydroxybenzoic 
acid alkyl esters. Emerging evidence has now revealed the endocrine-disrupting propensity of parabens based on their adverse impact on development and reproduction from both in vitro and in vivo studies $[9,10]$. In this review, we summarize the current advances in understanding paraben exposure in humans and the mechanisms by which parabens may increase breast cancer risks.

\section{Human Parabens Exposure}

Humans have continuous and repetitive exposure to parabens. Parabens, which act as preservatives to prevent the growth of microorganisms, are commonly absorbed or ingested daily from paraben-containing personal care products, such as lotions, deodorants, hair care products, shaving products, pharmaceuticals, textiles, clothes, and foods [11-13]. Parabens are distributed systemically once they enter the body through dermal or gastrointestinal absorption. Parabens have been detected in human tissues, blood, breast milk, placenta, and urine [14-16]. Among all the parabens that humans are exposed to, the four most common parabens detected in biological fluids are methylparaben (MP), ethylparaben (EP), propylparaben (PP), and butylparaben (BP) [11,15,17].

On the other hand, isobutyl (IsoBP), isopropyl (IsoPP), and benzyl (BzP) parabens are less commonly used in household products $[18,19]$. Parabens undergo hydrolysis by esterase to $p$-hydroxybenzoic acid in human skin, small intestine, and liver. The hydrolysis rate of esterase on parabens increases with the length of the paraben's side chain; as a result, $\mathrm{MP}$ is the most abundant parabens found intact in biological fluids. It remains debatable whether the levels of esterase are sufficient to hydrolyze all dermally applied parabens and whether individual variations in esterase levels or exposure to esterase inhibitors could result in incomplete hydrolysis [20-22]. However, it is believed that systemic free paraben levels are largely from dermal exposure due to relatively less active esterases in the skin compared to those in the intestinal and liver. High concentrations of the free form of parabens have been detected within hours after whole-body application [15]. Intact parabens that survive first-pass metabolism can bind to human serum albumin, which protects parabens from hydrolysis, and therefore facilitates greater accessibility of the free form of parabens to other tissues and the potential for bioaccumulation [14,23].

The major exposure of parabens in humans is believed to be through personal care products. MP, PP, EP, and BP (free and conjugated) have been detected in urine in $99.1 \%$, $92.7 \%, 42.4 \%$, and $47 \%$ of young children in the US, respectively, while comparable frequencies of each paraben were detected in the adult population [24,25]. The estimated total intake of parabens via personal care product usage ranges from $31-766 \mu \mathrm{g} / \mathrm{kg}$ body weight, with infants being at the upper end [11]. Humans can also be exposed to parabens through foods. The estimated total intake of parabens from foods is between $307-940 \mathrm{ng} / \mathrm{kg}$ body weight. The daily intake varies depending on the life stage, with infants having the highest total intake [11]. In addition, urine concentrations of parabens is considerably higher in women $(17-237 \mathrm{ng} / \mathrm{mL})$ compared to men $(0.5-79.1 \mathrm{ng} / \mathrm{mL})$ [17]. The levels of parabens in the human body seem to correlate with the amount and the frequency of exposure [26-28].

\section{Parabens Exposure and Breast Cancer}

Like many other EDCs, paraben exposure has been associated with poor reproductive health in women [29]. In a recent study, urinary parabens concentrations were associated with earlier breast development, pubic hair development, earlier menarche in girls, and earlier genital development in boys [30].

It has been postulated that exposure to some EDCs leads to exacerbated cell proliferation and tumor growth in the breasts $[2,4,31]$. To establish links between parabens and breast cancer, it is imperative to demonstrate the presence and localization of parabens within the breast tissue. Paraben levels in breast tissue extracted from axilla to sternum have been investigated [11,32]. MP was detected at approximately $16.6 \mathrm{ng}$ per gram of the breast tissue, higher than previously documented [19]. The tissue level of PP was $16.8 \mathrm{ng} / \mathrm{g}$, higher than MP. Other parabens, such as BP, EP, and IsoBP, were also detected, although at 
relatively lower levels [11]. However, no significant correlation was identified between the concentration of parabens and the location of breast tumors or the estrogen receptor status in the breast tumors. It has been shown that parabens have greater bioaccumulation within the outer areas (axilla and lateral) of the breast than the inner areas (mid and medial) [32]. The outer areas of the breast consist of more adipose tissue where the mammary glands are centrally located. Moreover, the detection and accumulation of parabens in the adipose tissue of the breast have been reported, possibly due to their moderate hydrophobicity [23]. Higher levels of parabens detected in the outer regions of the breasts might be associated with how deodorants are applied [32].

Perhaps due to the vast amount of exposure variability and weak estrogenicity of parabens (reviewed in more details below) compared to 17- $\beta$ Estradiol, epidemiological evidence directly linking parabens exposure with breast cancer is still limited. In one study, the association between the circulating level of xenoestrogens and mammographic breast density, a powerful risk factor for breast cancer, was investigated in postmenopausal women. No association was found between serum levels of BP or PP and the density of the breasts $[33,34]$. In a recent case-control study, paraben levels in spot urine samples from 711 women with breast cancer were analyzed and compared with the 598 women without breast cancer [35]. It was found that the highest quintiles of urinary MP (414-3174 $\mu \mathrm{g} / \mathrm{g}$ creatinine), PP (28-3116 $\mu \mathrm{g} / \mathrm{g}$ creatinine), and total parabens (551-3766 $\mu \mathrm{g} / \mathrm{g}$ creatinine) were associated with increased risks of breast cancer and allcause mortality [35]. In addition, the associations were affected by body mass index (BMI). Associations for breast cancer incidence were more pronounced among women with lower BMI $\left(\right.$ BMI $\left.<25.0 \mathrm{~kg} / \mathrm{m}^{2}\right)$ than among women with higher BMI $\left(\right.$ BMI $\left.\geq 25.0 \mathrm{~kg} / \mathrm{m}^{2}\right)$. In contrast, associations for mortality were shown to have an opposite trend with BMI [35]. In another case-control study with a multiethnic cohort, urinary parabens and other EDCs in 1032 post-menopausal women with breast cancer with different ethnic backgrounds and 1030 individually matched controls were analyzed [36]. Breast cancer risks in this multiethnic population were weakly inversely associated with paraben exposure [36]. It should be noted that prolonged daily exposure to a paraben mixture (i.e., more than one type of parabens), bioaccumulation, and interactions with other xenoestrogens can invoke local intracrine, paracrine, or endocrine changes, contributing to breast carcinogenesis [37]. Therefore, future investigations on the association of parabens with breast cancer are needed. Table 1 summarizes the strengths and limitations of human studies on parabens exposure and breast cancer.

Table 1. Summary of Human Studies on Paraben Exposure and Breast Cancer.

\begin{tabular}{|c|c|c|c|}
\hline & Conclusions & Strength & Limitations \\
\hline Darbre et al. 2004 [19]. & $\begin{array}{l}\text { Intact parabens were found in } \\
\text { the human breast tumor tissues. } \\
\text { MP was present at the highest } \\
\text { level and represented } 62 \% \text { of the } \\
\text { total parabens extracted from } \\
\text { breast tumor tissues. }\end{array}$ & $\begin{array}{l}\text { Demonstrated that after } \\
\text { exposure, a proportion of the } \\
\text { parabens can remain intact in } \\
\text { human body tissues. The levels } \\
\text { of parabens measured in this } \\
\text { study were comparable to the } \\
\text { levels of parabens used in } \\
\text { in vitro studies, indicating the } \\
\text { levels of parabens detected in } \\
\text { breast tissues could induce } \\
\text { estrogenic effects in the } \\
\text { human breast. }\end{array}$ & $\begin{array}{l}\text { Small sample size. Analytical } \\
\text { blank values might contain } \\
\text { parabens introduced from } \\
\text { other sources. }\end{array}$ \\
\hline
\end{tabular}


Table 1. Cont.

\begin{tabular}{|c|c|c|c|}
\hline & Conclusions & Strength & Limitations \\
\hline Barr et al. 2011 [32]. & $\begin{array}{l}\text { Parabens were detected across } \\
\text { the human breast from axilla to } \\
\text { sternum. PP was found at } \\
\text { significantly higher levels in the } \\
\text { axilla than mid or medial } \\
\text { regions of the breast. No } \\
\text { correlations were found } \\
\text { between paraben concentrations } \\
\text { and tumor location or tumor } \\
\text { estrogen receptor content. }\end{array}$ & $\begin{array}{l}\text { Measured at the earliest time } \\
\text { point possible after cancer } \\
\text { diagnosis and prior to any } \\
\text { cancer therapy. Investigated the } \\
\text { distribution of parabens across a } \\
\text { single breast. }\end{array}$ & $\begin{array}{l}\text { Parabens were detected in } \\
\text { breast tissues from human } \\
\text { subjects who self-reported as } \\
\text { non-underarm cosmetics } \\
\text { users. Parabens were } \\
\text { measured from breast tissues } \\
\text { adjacent to breast tumor but } \\
\text { not from tumor directly. It is } \\
\text { also unclear the relative } \\
\text { importance of long-term } \\
\text { accumulation and/or acute } \\
\text { exposure to the levels of } \\
\text { parabens in the breast tissue. }\end{array}$ \\
\hline Sprague et al. 2013 [34]. & $\begin{array}{l}\text { Serum concentrations of BP and } \\
\text { PP were modestly correlated, } \\
\text { but parabens concentrations } \\
\text { were not associated with } \\
\text { percentage breast density (a } \\
\text { marker of breast cancer risk). }\end{array}$ & $\begin{array}{l}\text { Evaluated mammographic } \\
\text { breast density in relation to } \\
\text { biological measures of } \\
\text { xenoestrogens, including } \\
\text { parabens. Serum measurements } \\
\text { may better reflect the } \\
\text { biologically relevant exposure } \\
\text { of the target organs. }\end{array}$ & $\begin{array}{l}\text { Only postmenopausal women } \\
\text { were enrolled in the study. } \\
\text { Single blood sample was } \\
\text { collected, which may only } \\
\text { reflect current exposure. The } \\
\text { study population was } \\
\text { predominately non-Hispanic } \\
\text { white. The results may not } \\
\text { apply to general population. }\end{array}$ \\
\hline Harley, et al. 2019 [30]. & $\begin{array}{l}\text { Peripubertal concentrations of } \\
\text { MP were associated with earlier } \\
\text { breast development, pubic hair } \\
\text { development, and menarche in } \\
\text { girls; peripubertal } \\
\text { concentrations of PP were } \\
\text { associated with earlier pubic } \\
\text { hair development in girls; } \\
\text { peripubertal PP concentrations } \\
\text { were associated with earlier } \\
\text { genital development in boys. }\end{array}$ & $\begin{array}{l}\text { Evaluated prenatal as well as } \\
\text { peripubertal parabens exposure. }\end{array}$ & $\begin{array}{l}\text { Urinary parabens only } \\
\text { reflected recent exposure. The } \\
\text { study population was limited } \\
\text { to Latino women and children } \\
\text { of low socioeconomic status. } \\
\text { Potential confounding factors } \\
\text { from other environmental } \\
\text { contaminants could not be } \\
\text { ruled out. Associations of } \\
\text { peripubertal measurements } \\
\text { with parabens may reflect } \\
\text { reverse causality because } \\
\text { children going through } \\
\text { puberty earlier may be more } \\
\text { likely to use personal } \\
\text { care products. }\end{array}$ \\
\hline Parada et al. 2020 [35]. & $\begin{array}{l}\text { The highest (vs. lowest) } \\
\text { quintiles of urinary MP, PP, and } \\
\text { total parabens were associated } \\
\text { with the risk of breast cancer. } \\
\mathrm{MP}, \mathrm{PP} \text {, and total parabens were } \\
\text { inversely associated with } \\
\text { all-cause mortality hazard } \\
\text { ratios. }\end{array}$ & $\begin{array}{l}\text { A case-control and follow up } \\
\text { design. Large sample size. } \\
\text { Participants included women } \\
\text { with breast cancer and women } \\
\text { without breast cancer. Among } \\
\text { women with breast cancer, } \\
\text { phenol biomarkers were } \\
\text { quantified in urine samples. } \\
\text { Women with breast cancer were } \\
\text { monitored for vital status with a } \\
\text { median follow-up of } 17.6 \text { years. } \\
\text { Examined whether urinary } \\
\text { phenol biomarkers were } \\
\text { associated with mortality } \\
\text { following breast cancer. }\end{array}$ & $\begin{array}{l}\text { A single spot urine sample } \\
\text { may not be a reliable reflection } \\
\text { of women's parabens } \\
\text { exposure. In addition, urine } \\
\text { samples from breast cancer } \\
\text { patients were collected after } \\
\text { not before their diagnosis. }\end{array}$ \\
\hline
\end{tabular}


Table 1. Cont.

\begin{tabular}{|c|c|c|c|}
\hline & Conclusions & Strength & Limitations \\
\hline Wu et al. 2021 [36]. & $\begin{array}{l}\text { Breast cancer risk was weakly } \\
\text { inversely associated with total } \\
\text { (but not individual) parabens } \\
\text { exposure. Risk of hormone } \\
\text { receptor positive (HR+) cancer } \\
\text { was lower among women in the } \\
\text { upper two tertiles of } \\
\text { paraben exposure. }\end{array}$ & $\begin{array}{l}\text { A multiethnic population-based } \\
\text { nested case-control study. } \\
\text { Examined the association } \\
\text { between breast cancer risk and } \\
\text { prediagnostic exposures } \\
\text { paraben. Potential differences in } \\
\text { terms of hormone receptor } \\
\text { status, tumor stage (invasive vs } \\
\text { in situ) and the length of } \\
\text { follow-up time were considered } \\
\text { in the analysis. }\end{array}$ & $\begin{array}{l}\text { All cases and controls were } \\
\text { postmenopausal at the time of } \\
\text { urine collection. A single } \\
\text { measure of parabens to } \\
\text { capture long-term exposures } \\
\text { could lead to misclassification } \\
\text { of exposure. }\end{array}$ \\
\hline
\end{tabular}

\section{Estrogenic Effects of Parabens}

Despite the limited epidemiological evidence linking paraben exposure with breast cancer, recent in vitro and animal studies have shed light on the endocrine-modulating effects of parabens, suggesting that parabens may be implicated in breast carcinogenesis.

Estrogen is the primary sex hormone responsible for mammary gland development during critical life stages $[38,39]$. The pubertal surge of secretion of estrogen and progesterone from the ovaries stimulates proliferation of the myoepithelial cells within ducts [40,41]. In addition, estrogen induces growth and branching of mammary ducts in cooperation with other growth factors by activating the estrogen receptors (ER) located in the epithelium and stromal cells [42-44].

The estrogenic activity of parabens has been well documented and characterized [2,10,45-50]. Parabens have been shown to regulate ER-mediated gene expression in vitro [2,45-48]. MP, EP, PP, $\mathrm{BP}$, and BzP have an estradiol equivalence factor (EEF) of $1.25 \times 10^{-7}, 6.48 \times 10^{-7}, 2.39 \times 10^{-6}$, $8.09 \times 10^{-6}$, and $1.35 \times 10^{-5}$ respectively [13]. In silico simulation has shown that MP and EP interact with the agonist-binding pocket of human ER $\alpha$. MP and EP bound to Glu353 and Arg394 of human ER with binding energies of -49.35 and $-53.38 \mathrm{kcal} / \mathrm{mol}$, respectively. Both Glu353 and Arg394 are located at the ligand-binding pocket of the ER known to play a critical role in human ER $\alpha-17 \beta$-estradiol (E2) interaction [49]. The values of the negative binding energy indicate that the binding of parabens to ER $\alpha$ is likely to be a spontaneous process. The stimulatory effects on the proliferation of breast cancerous MCF-7 and noncancerous MCF-10A cells in response to either a single or repetitive exposure to MP, $\mathrm{PP}$, or BP were studied [51]. While all tested parabens increased cell proliferation of MCF-7 cells, only $\mathrm{MP}$ and BP at low doses increased MCF-10A cells proliferation after a single exposure, but not repeated exposure. Moreover, MP, PP, and BP exposure at low doses significantly increased E2 secretion in MCF-7 cells, but they all had the opposite effect on MCF-10A cells [51]. Table 2 summarizes the differential effects of parabens on the gene expression of ER and progesterone receptor (PR) in MCF 7 vs. MCF-10 A cells [52]. Interesting, the effect of parabens on ER $\alpha$ and ER $\beta$ can be effectively blocked by ICI 182,780, the ER antagonist, in the MCF-7 cells [52]. In contrast, co-treatment with ICI 182,780 did not attenuate the stimulatory effect of parabens on either ER $\alpha$ or ER $\beta$ in the MCF-10A cells [52]. $\mathrm{ER} \alpha$ and $\mathrm{ER} \beta$ seem to play opposing roles in regulating growth and differentiation in response to estrogens in the breasts [53,54]. PR, an estrogen-regulated protein, is among the most important prognostic and predictive markers of response to endocrine therapies in breast cancer patients [55]. PR acts as a critical factor in the induction, progression, and maintenance of the neoplastic phenotype of ER-positive breast cancer [56]. Future studies are warranted to understand the biological implications of differential actions of parabens on ERs and PR in cancerous vs. noncancerous breast epithelial cells. 
Table 2. Effect of 17ß-estradiol (E2) and Parabens on Estrogen and Progesterone Receptors Gene and Protein Expression [52].

\begin{tabular}{|c|c|c|c|c|c|c|c|c|}
\hline & \multicolumn{8}{|c|}{ MCF-7 } \\
\hline & \multicolumn{4}{|c|}{$\mathrm{ER} \alpha$} & \multicolumn{4}{|c|}{ PR } \\
\hline & \multicolumn{2}{|c|}{ mRNA } & \multicolumn{2}{|c|}{ Protein } & \multicolumn{2}{|c|}{ mRNA } & \multicolumn{2}{|c|}{ Protein } \\
\hline & $6 \mathrm{~h}$ & $24 \mathrm{~h}$ & $48 \mathrm{~h}$ & $72 \mathrm{~h}$ & $6 \mathrm{~h}$ & $24 \mathrm{~h}$ & $48 \mathrm{~h}$ & $72 \mathrm{~h}$ \\
\hline MP & $\mathrm{NC}$ & $\uparrow$ & $\uparrow$ & $\uparrow$ & $\mathrm{NC}$ & $\mathrm{NC}$ & $\uparrow$ & $\uparrow$ \\
\hline $\mathrm{BP}$ & $\mathrm{NC}$ & $\uparrow$ & $\uparrow$ & $\mathrm{NC}$ & $\mathrm{NC}$ & $\uparrow$ & $\mathrm{NC}$ & $\mathrm{NC}$ \\
\hline PP & $\mathrm{NC}$ & $\uparrow$ & $\uparrow$ & $\mathrm{NC}$ & $\mathrm{NC}$ & $\uparrow$ & $\uparrow$ & $\uparrow$ \\
\hline \multirow[t]{5}{*}{ E2 } & $\mathrm{NC}$ & $\uparrow$ & $\uparrow$ & $\uparrow$ & $\uparrow$ & $\uparrow$ & $\uparrow$ & $\uparrow$ \\
\hline & \multicolumn{8}{|c|}{ MCF-10A } \\
\hline & \multicolumn{4}{|c|}{$\mathrm{ER} \alpha$} & \multicolumn{4}{|c|}{ PR } \\
\hline & \multicolumn{2}{|c|}{ mRNA } & \multicolumn{2}{|c|}{ Protein } & \multicolumn{2}{|c|}{ mRNA } & \multicolumn{2}{|c|}{ Protein } \\
\hline & $6 \mathrm{~h}$ & $24 \mathrm{~h}$ & $48 \mathrm{~h}$ & $72 \mathrm{~h}$ & $6 \mathrm{~h}$ & $24 \mathrm{~h}$ & $48 \mathrm{~h}$ & $72 \mathrm{~h}$ \\
\hline MP & $\uparrow$ & $\mathrm{NC}$ & $\uparrow$ & $\uparrow$ & $\mathrm{NC}$ & $\mathrm{NC}$ & $\mathrm{NC}$ & $\mathrm{NC}$ \\
\hline $\mathrm{BP}$ & $\mathrm{NC}$ & $\mathrm{NC}$ & $\mathrm{NC}$ & $\mathrm{NC}$ & $\mathrm{NC}$ & $\uparrow$ & $\mathrm{NC}$ & $\mathrm{NC}$ \\
\hline PP & $\uparrow$ & $\mathrm{NC}$ & $\mathrm{NC}$ & $\uparrow$ & $\mathrm{NC}$ & $\uparrow$ & $\mathrm{NC}$ & $\mathrm{NC}$ \\
\hline \multirow[t]{5}{*}{ E2 } & $\mathrm{NC}$ & $\uparrow$ & $\uparrow$ & $\uparrow$ & $\mathrm{NC}$ & $\mathrm{NC}$ & $\mathrm{NC}$ & $\mathrm{NC}$ \\
\hline & \multicolumn{4}{|c|}{ MCF-7 } & \multicolumn{4}{|c|}{ MCF-10A } \\
\hline & \multicolumn{4}{|c|}{$E R \beta$} & \multicolumn{4}{|c|}{$\mathrm{ER} \beta$} \\
\hline & \multicolumn{2}{|c|}{ mRNA } & \multicolumn{2}{|c|}{ Protein } & \multicolumn{2}{|c|}{ mRNA } & \multicolumn{2}{|c|}{ Protein } \\
\hline & $6 \mathrm{~h}$ & $24 \mathrm{~h}$ & $48 \mathrm{~h}$ & $72 \mathrm{~h}$ & $6 \mathrm{~h}$ & $24 \mathrm{~h}$ & $48 \mathrm{~h}$ & $72 \mathrm{~h}$ \\
\hline MP & $\mathrm{NC}$ & $\uparrow$ & $\uparrow$ & $\uparrow$ & $\mathrm{NC}$ & $\mathrm{NC}$ & $\mathrm{NC}$ & $\uparrow$ \\
\hline $\mathrm{BP}$ & $\mathrm{NC}$ & $\uparrow$ & $\uparrow$ & $\mathrm{NC}$ & $\mathrm{NC}$ & $\mathrm{NC}$ & $\mathrm{NC}$ & $\uparrow$ \\
\hline PP & $\mathrm{NC}$ & $\uparrow$ & $\uparrow$ & $\mathrm{NC}$ & $\mathrm{NC}$ & $\mathrm{NC}$ & $\mathrm{NC}$ & $\uparrow$ \\
\hline E2 & $\mathrm{NC}$ & $\uparrow$ & $\uparrow$ & $\uparrow$ & $\mathrm{NC}$ & $\mathrm{NC}$ & $\mathrm{NC}$ & $\mathrm{NC}$ \\
\hline
\end{tabular}

MCF-7 and MCF-10 A cells were exposed to parabens (20 nM) or E2 (10 nM); Gene expression was evaluated at 6 and 24 hours post treatment. Protein expression was evaluated at 48 and 72 hours post treatment. Up arrow: Upregulation; NC: No change.

The differential effect of parabens on the expression of genes related to cell cycle control and apoptosis has been investigated in MCF-7 and MCF-10A cells [57]. As shown in Table 3, these results further demonstrated variabilities in gene expression between cancerous and noncancerous breast epithelial cell lines in response to parabens. The discrepancy in cellular behavior between cancerous and noncancerous breast epithelia in response to parabens may suggest that parabens' effects could be cell type-specific.

Table 3. Effect of 17- $\beta$ Estradiol (E2) and Parabens on the Expression of Selected Genes in MCF-7 and MCF-10A [57].

\begin{tabular}{|c|c|c|c|c|c|c|c|c|c|c|c|c|c|c|}
\hline & & \multicolumn{13}{|c|}{ MCF-7 } \\
\hline & Genes & CCND1 & CCND3 & CCNE1 & CCNE2 & CCNA2 & CDK2 & CDK4 & CDK6 & CDKN1A & ATR & ATM & E2F3 & TP53 \\
\hline E2 & & $\uparrow$ & $\uparrow$ & $\mathrm{NC}$ & $\uparrow$ & $\uparrow$ & $\uparrow$ & $\uparrow$ & $\downarrow$ & $\uparrow$ & $\uparrow$ & $\downarrow$ & $\downarrow$ & $\mathrm{NC}$ \\
\hline MP & & NC & NC & $\downarrow$ & NC & NC & NC & NC & $\downarrow$ & NC & $\uparrow$ & $\downarrow$ & NC & $\mathrm{NC}$ \\
\hline PP & & NC & NC & $\uparrow$ & NC & NC & $\uparrow$ & $\mathrm{NC}$ & $\downarrow$ & NC & $\uparrow$ & $\downarrow$ & $\downarrow$ & NC \\
\hline \multirow[t]{3}{*}{ BP } & & NC & $\uparrow$ & $\downarrow$ & $\uparrow$ & $\mathrm{NC}$ & $\mathrm{NC}$ & $\mathrm{NC}$ & $\downarrow$ & NC & $\uparrow$ & $\downarrow$ & $\downarrow$ & NC \\
\hline & & \multicolumn{13}{|c|}{ MCF-10A } \\
\hline & Genes & CCND1 & CCND3 & CCNE1 & CCNE2 & CCNA2 & CDK2 & CDK4 & CDK6 & CDKN1A & ATR & ATM & E2F3 & TP53 \\
\hline E2 & & $\uparrow$ & $\mathrm{NC}$ & $\uparrow$ & $\uparrow$ & $\mathrm{NC}$ & $\uparrow$ & $\uparrow$ & $\mathrm{NC}$ & $\downarrow$ & $\mathrm{NC}$ & $\mathrm{NC}$ & $\uparrow$ & $\uparrow$ \\
\hline $\mathrm{MP}$ & & $\uparrow$ & NC & $\uparrow$ & NC & $\uparrow$ & $\uparrow$ & $\uparrow$ & $\downarrow$ & $\downarrow$ & NC & NC & $\uparrow$ & NC \\
\hline $\mathrm{PP}$ & & $\uparrow$ & $\downarrow$ & $\uparrow$ & NC & $\uparrow$ & $\uparrow$ & $\uparrow$ & $\mathrm{NC}$ & $\downarrow$ & NC & $\uparrow$ & $\uparrow$ & $\uparrow$ \\
\hline BP & & $\uparrow$ & $\downarrow$ & $\uparrow$ & $\uparrow$ & $\uparrow$ & $\uparrow$ & $\uparrow$ & $\uparrow$ & $\downarrow$ & $\uparrow$ & $\uparrow$ & $\uparrow$ & $\mathrm{NC}$ \\
\hline
\end{tabular}


Global changes in gene expression profiles in response to parabens or E2 treatment have been studied in MCF-7 cells [58]. MCF-7 cells treated for 3 days with EP, PP, and $\mathrm{BP}$, but not MP, showed gene expression profiles that correlated well with those genes in response to E2 treatment and the length of the alkyl chain of parabens was crucial for the estrogen-like profiles [58]. MCF-7 cells were also treated with $5 \times 10^{-4} \mathrm{M} \mathrm{MP}$, $10^{-5} \mathrm{M} \mathrm{BP}$, or $10^{-8} \mathrm{M}$ E2 for 7 days and the global gene expression profiles in response to the treatments were compared [59]. Of the 19,881 human genes investigated, 1972 genes were altered by $\geq 2$-fold by MP, 1,292 genes were altered by $\geq 2$-fold by BP, and 857 genes were altered $\geq 2$-fold by E2. Only 61 genes were upregulated $\geq 2$-fold by MP, BP and E2, while 198 genes were downregulated by $\geq 2$-fold by all three test compounds [59]. Therefore, the majority of genes did not follow the same pattern of regulation by all three treatments in MCF-7 cells [59]. These results demonstrated that although parabens are estrogenic, their mimicry of E2 in global gene expression patterns is not perfect. Differences in gene expression profiles in cells in response to parabens could lead to different biological and developmental trajectories compared to the cells exposed to E2 [59].

In vivo studies of the effects of parabens on dynamic histological changes in mammary gland development have been studied in Sprague-Dawley rats [60]. Compared to the rats treated with the vehicle control, MP at doses that mimic human exposure levels during perinatal, prepuberty, and puberty significantly decreased amount of adipose tissue while increased expansion of the ductal tree and/or elevated amount of glandular tissue with a higher degree of branching. The authors identified puberty as the window of heightened sensitivity to MP, with increased glandular tissue and differential expression of 295 genes with significant enrichment of genes involved in DNA replication and cell cycle regulation [60]. It is worth noting that the genes modified by MP are also well represented in the gene signature profiles of human breast cancer, suggesting a possible link between MP exposure during the critical window of breast development and a higher risk of breast cancer [60].

In vivo studies of the effects of parabens on breast cancer initiation and progression are still scarce. In one study, MP at the levels that are commonly used in personal care products promoted the development of larger tumors than the placebo treatment in the nude mice xenografted with ER+ MCF-7 cells. Similarly, MP treatment significantly increased the volume of human patient-derived xenograft breast tumors compared to the placebo [61]. Additional in vivo studies using different breast cancer animal models are necessary to understand the full extent of the effects of parabens on breast cancer development.

\section{The Nongenomic Activity of Parabens}

In addition to nuclear receptors $\mathrm{ER} \alpha$ and $\mathrm{ER} \beta$, membrane-bound G-protein-coupled estrogen receptor (GPER, GPR30 or GPER1) also binds to estrogens and activates downstream signaling events $[62,63]$. GPER acts through protein-kinase cascade, such as ERK1/2, and is involved in various physiological and pathological processes, including cancer progression $[64,65]$. GPER signaling regulates matrix metalloproteinases (MMPs), which are a group of enzymes that helps rearrange the tissue microenvironment and enable cancer metastasis [66-69]. GPER is highly expressed in cancerous breast epithelial cells and tumors, especially in those that are less responsive to ER $\alpha$ inhibitors treatment [63]. A three-dimensional (3D) culture of immortalized MCF-12A (ER $\alpha+, \mathrm{ER} \beta+$, and GPER+) was used to model the features and behavior of the breast epithelium in vivo [70]. Treatment with PP at $10 \mu \mathrm{M}$ for 16 days resulted in deformed acini and filling of the acinar lumen of the mammospheres, which could be reversed by both ER and GPER inhibitors [70]. In contrast, another study examined the elongation of MRC5 cells, an immortalized human lung fibroblast cell line expressing GPER, but not ER $\alpha$, in response to parabens [71]. GPER agonists induce MRC5 cell elongation. However, neither MP $(0.1 \mu \mathrm{M})$ nor EP $(1.0 \mu \mathrm{M})$ showed GPER agonist activities in these cells [71]. Taken together, these results suggest that classical nuclear estrogen receptors might be required for parabens to act through GPER [71]. 


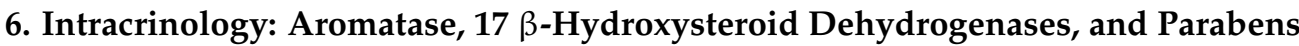

It is recognized that it is not just circulating levels of estrogens that matter. The local microenvironment affected by estrogens produced in situ through the intracrine mechanism is also critical [72,73]. Aromatase is involved in converting androgen to estrogen and contributes to the intracrine pathway that stimulates the growth of normal breast epithelial cells and cancer cells. Treatment of MP or PP induced aromatase (CYP19A1) mRNA and protein expression in MCF-7 cells [51]. Consistently, parabens increased estradiol production in MCF-7 cells [51]. In contrast, MP, PP, and BP decreased CYP19A1 mRNA and aromatase protein expression in noncancerous MCF-10A cells, resulting in decreased estradiol production in MCF-10A cells. Moreover, it was reported that MP, EP, $\mathrm{PP}, \mathrm{BP}$, isoPP, and BzP dose-dependently inhibited aromatase activity in human placentaderived microsomes [74]. Aromatase expression is tissue-specific and tightly controlled by local signals activating alternative promoters in a timely and cell-specific manner $[75,76]$. Therefore, the discrepancy of the findings between the two studies [51,74]. suggests that parabens may modulate aromatase expression in a cell- and tissue-specific manner.

In post-menopausal women, the ovarian source of estrogens is greatly diminished. Consequently, the primary source of active estrogen in breast tissue is local steroid conversion. In breast tissue, $17 \beta$-hydroxysteroid dehydrogenases (17 $\beta$-HSD1 and 17 $\beta$-HSD2) regulate the local balance between potent and weak estrogens. $17 \beta-$ HSD1 catalyzes the reduction of 17-ketosteroids and is responsible for converting the weak estrogenic estrone (E1) into E2; $17 \beta-H S D 2$, on the other hand, oxidizes $17 \beta$-hydroxysteroids and decreases the local concentrations of strong estrogen E2 [77]. A high $17 \beta-H S D 2$ to $17 \beta-H S D 1$ ratio positively correlates with the survival of ER $\alpha$-positive breast cancer patients [77-79]. The relative expression of the $17 \beta-H S D$ s, combined with the availability of substrates, was shown to determine the final biological impact of the sex steroids on the local tissue [80]. It has been reported that $\mathrm{MP}, \mathrm{EP}, \mathrm{PP}$, IsoPP, BP, IsoBP, phenylparaben (PhP), hexylparaben $(\mathrm{HeP}), \mathrm{BzP}$, and heptylparaben (HepP) but not the common metabolite $p$-hydroxybenzoic acid, inhibited $17 \beta-H S D 2$ expression at $20 \mu \mathrm{M}$ [81]. Parabens also size-dependently inhibited $17 \beta-H S D 1$ with HexP and HepP having the most potent inhibition, whereas MP and EP had no effects on 17 $\beta$-HSD1 [81]. MP, EP, and PP are smaller parabens and are among the most commonly used parabens compared to their larger counterparts; therefore, $17 \beta-\mathrm{hsd} 2$ inhibition is more likely to occur and is physiologically more relevant than $17 \beta-H S D 1$ inhibition by parabens [81]. Moreover, smaller parabens, such as EP, have a more efficient inhibition of $17 \beta-\mathrm{HSD} 2$ with an $\mathrm{IC}_{50}$ in the low micromolar range [81], than their binding to $\mathrm{ER}$ with an $\mathrm{EC}_{50}$ in the millimolar range [82]. Therefore, the inhibition of $17 \beta-\mathrm{HSD} 2$ and the subsequently elevated local estradiol concentrations by smaller parabens are more likely to disturb the regulation of estrogenic target genes than their direct action through binding to ERs [81]. These results suggest that the estrogenic action of parabens should not be simply evaluated based on their ER binding capabilities. The modulations of key intracrine enzymes and the synergistic or additive inhibitory effects of paraben mixtures on $17 \beta$-HSDs should be investigated to provide a complete picture of parabens' effects on the local tissue environment.

\section{Antiandrogenic Effects of Parabens}

The alternation of endogenous androgen levels also plays an important role in breast cancer development. A high level of circulating testosterone increases the breast cancer risk in pre-menopausal women. Also, androgen level is a strong prognostic factor for local relapse, contralateral breast cancer, and distant metastases in post-menopausal women [83-86]. Androgen treatment inhibited cell proliferation and increased apoptosis of some breast cancer cell lines but stimulated proliferation of other breast cancer cells [87-89]. In HEK293 cells transfected with androgen receptor (AR), parabens (MP, BP, and PP) at $10 \mu \mathrm{M}$ inhibited the transcriptional activity of testosterone by $40 \%, 33 \%$, and $19 \%$, respectively [20]. Similarly, the antiandrogen activities of IsoBP, BP, isoPP, and PP were reported using $\mathrm{CHO}-\mathrm{K} 1$ cells stably transfected with AR [90]. In this study, no antiandrogenic 
activities were detected for EP and MP [90]. In contrast, in MDA-kb2 cells transfected with MMTV-driven luciferase, moderate antagonizing effects of MP and EP against dihydrotestosterone (DHT) were detected while PP, BP, [91]. or BzP showed no antiandrogenic activity [92]. These results may reflect different cell models used in the studies. Naïve HEK293 and CHO-K1 lack endogenous ARs, while MDA-kb2 cells express both endogenous $\mathrm{AR}$ and glucocorticoid receptors (GRs). Compounds that interfere with either receptor are expected to affect the MMTV-driven luciferase activities in the MDA-kb2 cells transfected with either reporter. Parabens, BP and BzP in particular, are known to have GR-agonist activities [93]. Therefore, the GR-mediated luciferase activity induced by BP and BzP could have obscured their inhibition of DHT-mediated luciferase activity.

\section{Crosstalk with Human Epidermal Growth Factor Receptor 2 Pathway by Parabens}

Parabens have been shown to crosstalk with other cell signaling pathways in breast cancer development. Human epidermal growth factor receptor 2 (HER2) is a transmembrane protein of the epidermal growth factor receptor family. Autophosphorylation of tyrosine residues upon receptor dimerization activates and initiates a cascade of cell signaling events, including PI3K/Akt/mTORC2, which regulates cell proliferation, malignant transformation, and tumorigenesis [94-96]. Approximately one-fourth of breast cancers overexpress HER2 [97], which is a negative prognostic indicator. The interplay between HER2 and ER signaling pathways in breast cancer is considered multidirectional and complex [98,99].

Pan and colleagues have investigated the interaction of parabens with breast cancerrelated signaling pathways [99]. Both PP and BP effectively increased pro-oncogenic $c-M y c$ mRNA expression in BT-474 cells (ER+/HER2+). The increase in $c-M y c$ mRNA by PP and BP was further enhanced by heregulin (HRG), a HER2 ligand [99]. Co-treatment with HRG and parabens significantly increased c-Myc protein expression in BT-474 cells. The combination of BP and HRG synergistically stimulated the proliferation of BT-474 cells compared with the effects of BP alone, and the synergy was abolished by classic ER antagonists [99].

In contrast, there was no synergy on c-Myc protein expression in ER $\alpha$ negative SKBR3 cell line $(\mathrm{ER} \alpha-/ \mathrm{HER} 2+)$. These results indicate that the synergy between HRG and BP is $\mathrm{ER} \alpha$ dependent [99]. Intriguingly, in MCF-7 cells, which are ER $\alpha$ positive but HER2 negative, HRG and BP co-treatment also significantly enhanced the induction of c-Myc protein [99]. These findings suggest that other signaling pathways from the HER family may also involve in the effects of HRG on the estrogenic effect of parabens in breast cancer cells. Moreover, these findings underscore the urgent need to re-assess the "weak" estrogenic effects of parabens, particularly at environmentally achievable doses, in the presence of other factors that crosstalk and act in concert with ER signaling pathways to modulate breast cancer cell growth and development.

\section{Anchorage Independence, Migration, and Parabens}

Increased cell proliferation is not the only hallmark of cancerous cells. The ability of cells to grow from anchorage-dependent to anchorage-independent predicts the tendency to form tumors in vivo [100]. It was reported that MP, BP, and PP induced anchorage-independent growth of non-transformed breast epithelial MCF-10A cells in semi-solid suspension culture, which has provided additional evidence to link parabens in breast carcinogenesis [100]. Over time, the cancerous epithelial cells can acquire the attributes of mesenchymal cells through a dedifferentiation process, namely, epithelial-to-mesenchymal transitions (EMT) [101-103]. Once breast cancer cells have undergone EMT, they can function as mesenchymal cells to migrate through the basement membrane and into circulation, leading to metastasis. A study has indicated that long-term exposure (20 \pm 2 weeks) of MCF-7 cells to MP, PP, and BP increased migration as measured by scratch assays and with time-lapse microscopy [104]. Long-term MP, PP, and BP treatment also increased the invasive properties of MCF-7 cells as measured by matrix degradation assays and migration through Matrigel [104]. Further analysis indicated that parabens downregulated cell adhesion molecule E-cadherin and $\beta$-catenin in the MCF-7 cells. Similar results were obtained from another two other estrogen responsive cell lines 
T-47-D and ZR-75-1 [104]. These results suggest that parabens may promote EMT in the cancerous breast epithelial cells.

\section{Conclusions and Future Perspectives}

Parabens are a group of EDCs commonly found in personal care products, foods, and pharmaceuticals. Systemic exposure to parabens has been confirmed by the ubiquitous detection of parabens in human blood and urine samples. The main concerns regarding parabens use in consumer products are their potential mimicry of endogenous hormones, possible cross-talks with other signal transduction pathways, such as HER2 signaling pathway, that are pivotal in the development of breast cancer, and modulation of key enzymes involved in local estrogen metabolism. Estrogen receptor is a key transcriptional factor that drives the oncogenesis and growth of hormonally sensitive breast cells. However, the recurrence and resistance to endocrine therapy of certain types of breast cancer, indicate that underlying mechanisms of breast cancer development are likely complex, involving multiple signaling pathways. Figure 1 highlights some possible mechanisms by which parabens affect breast cancer development.

Although some research findings have suggested that parabens may negatively interfere with some endocrine targets relevant to breast carcinogenesis, evidence from in vivo and epidemiological studies linking paraben exposure to breast cancer is limited. So far, most studies have focused on one single paraben and/or the direct modulating effects of parabens on sex hormone receptors. Parabens are known to have significantly lower binding affinities to estrogen receptors than their endogenous counterparts. Therefore, the direct link of the estrogenic effect of parabens to breast carcinogenesis is debatable.

Future studies investigating paraben mixtures and their cross-talks with other EDCs or signaling pathways both in vivo and in vitro are warranted. For now, cautions should be taken when individuals, including breast cancer patients or individuals with high risk of breast cancer, make the decisions on personal care products containing parabens.
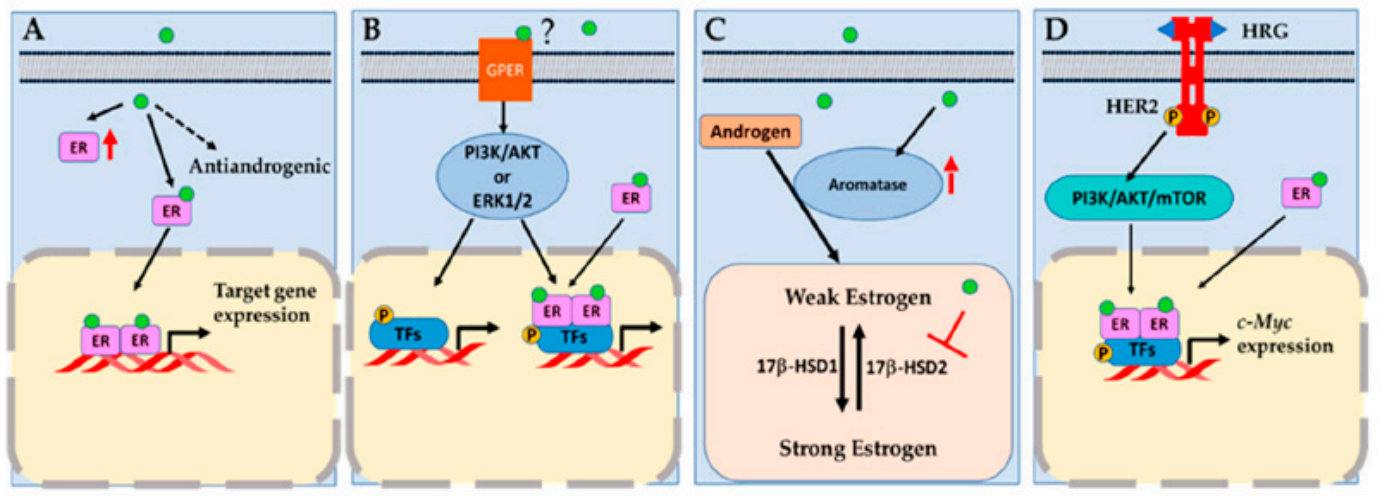

A. Estrogenic and antiandrogenic effects of parabens. Parabens (shown as light green circles) bind to ER or increase ER expression to induce target gene expression.

B. The non-genomic activity of parabens. Parabens act through membrane-bound G-protein coupled estrogen receptor (GPER) to induce target gene expression. TF: transcription factor.

C. Intracrinology. Parabens modulate local estrogen levels by inducing aromatase, which converts androgens to estrogens or inhibiting $17 \beta$-HSD2, which oxidizes strong estrogen to weak estrogen.

D. Crosstalk with human epidermal growth factor receptor 2 (HER2) by parabens. Parabens synergistically act with HER2 ligand (HRG) to induce oncogenic c-Myc expression in the presence of ER activation. TF: transcription factor. Blue triangle: HER2 ligand, Heregulin (HRG).

Figure 1. Molecular mechanisms by which parabens act in breast cancer cells. 
Author Contributions: Writing —original draft preparation, E.H.; writing—review and editing, E.H., J.C. and L.Z.; project administration, L.Z.; funding acquisition, L.Z. All authors have read and agreed to the published version of the manuscript.

Funding: This research was partially funded by NIH, grant number 1R15DK114790-01A1.

Institutional Review Board Statement: Not applicable.

Informed Consent Statement: Not applicable.

Data Availability Statement: Not applicable.

Acknowledgments: We want to thank Zhao lab members for their helpful discussion.

Conflicts of Interest: The authors declare no conflict of interest. The funders had no role in writing the manuscript or in the decision to publish the paper.

\begin{tabular}{|c|c|}
\hline 17ß-HSD1 & $17 \beta$-hydroxysteroid dehydrogenases type 1 \\
\hline 17ß-HSD2 & $17 \beta$-hydroxysteroid dehydrogenases type 2 \\
\hline $\mathrm{AR}$ & Androgen receptor \\
\hline ATM & Ataxia telangiectasia mutated \\
\hline ATR & Ataxia telangiectasia and Rad3 related \\
\hline $\mathrm{BP}$ & Butylparaben \\
\hline BMI & Body mass index \\
\hline $\mathrm{BzP}$ & Benzylparaben \\
\hline CCND1 & Cyclin D1 \\
\hline CCND3 & Cyclin D3 \\
\hline CCNE1 & Cyclin E1 \\
\hline CCNE2 & Cyclin E2 \\
\hline CCNA2 & Cyclin A2 \\
\hline CDK2 & Cyclin Dependent Kinase 2 \\
\hline CDK4 & Cyclin Dependent Kinase 4 \\
\hline CDK6 & Cyclin Dependent Kinase 6 \\
\hline CDKN1A & Cyclin Dependent Kinase Inhibitor 1A \\
\hline CYP19A1 & cytochrome P450 19A1 (aromatase) \\
\hline DHT & Dihydrotestosterone \\
\hline E2F3 & Transcription factor E2F3 \\
\hline EEF & Estradiol equivalence factor \\
\hline E1 & Estrone \\
\hline E2 & $17 \beta$-estradiol \\
\hline ER & Estrogen receptor \\
\hline EDCs & Endocrine-disruptive chemicals \\
\hline EMT & Epithelial-to-mesenchymal transitions \\
\hline EP & Ethylparaben \\
\hline GPER & G-protein-coupled estrogen receptor (GPR30 or GPER1) \\
\hline GR & Glucocorticoid receptor \\
\hline $\mathrm{HeP}$ & hexylparaben \\
\hline HepP & Heptylparaben \\
\hline HER2 & Human epidermal growth factor receptor 2 \\
\hline HRG & Heregulin \\
\hline IsoBP & Isobutylparaben \\
\hline IsoPP & Isopropylparaben \\
\hline MMPs & Matrix metalloproteinases \\
\hline MP & Methylparaben \\
\hline $\mathrm{PhP}$ & Phenylparaben \\
\hline PR & Progesterone receptor \\
\hline PP & Propylparaben \\
\hline TP53 & Tumor protein p53 \\
\hline
\end{tabular}




\section{References}

1. ACS. About Breast Cancer. 2021. Available online: https://www.cancer.org/cancer/breast-cancer.html (accessed on 30 December 2021).

2. Darbre, P.D. Environmental oestrogens, cosmetics and breast cancer. Best Pract. Res. Clin. Endocrinol. Metab. 2006, 20, 121-143. [CrossRef] [PubMed]

3. Ghosn, B.; Benisi-Kohansal, S.; Ebrahimpour-Koujan, S.; Azadbakht, L.; Esmaillzadeh, A. Association between healthy lifestyle score and breast cancer. Nutr. J. 2020, 19, 4. [CrossRef] [PubMed]

4. Rodgers, K.M.; Udesky, J.O.; Rudel, R.A.; Brody, J.G. Environmental chemicals and breast cancer: An updated review of epidemiological literature informed by biological mechanisms. Environ. Res. 2018, 160, 152-182. [CrossRef] [PubMed]

5. Darbre, P.D. Endocrine disrupting chemicals and breast cancer cells. Adv. Pharm. 2021, 92, 485-520.

6. Wan, M.L.Y.; Co, V.A.; El-Nezami, H. Endocrine disrupting chemicals and breast cancer: A systematic review of epidemiological studies. Crit. Rev. Food Sci. Nutr. 2021, 5, 1-27, Online ahead of print. [CrossRef]

7. La Merrill, M.A.; Vandenberg, L.N.; Smith, M.T.; Goodson, W.; Browne, P.; Patisaul, H.B.; Guyton, K.Z.; Kortenkamp, A.; Cogliano, V.J.; Woodruff, T.J.; et al. Consensus on the key characteristics of endocrine-disrupting chemicals as a basis for hazard identification. Nat. Rev. Endocrinol. 2020, 16, 45-57. [CrossRef]

8. NIEHS. Endocrine Disruptors. 2021. Available online: https://www.niehs.nih.gov/health/topics/agents/endocrine/index.cfm (accessed on 30 December 2021).

9. Nowak, K.; Ratajczak-Wrona, W.; Górska, M.; Jabłońska, E. Parabens and their effects on the endocrine system. Mol. Cell Endocrinol. 2018, 474, 238-251. [CrossRef]

10. Karpuzoglu, E.; Holladay, S.D.; Gogal, R.M., Jr. Parabens: Potential impact of low-affinity estrogen receptor binding chemicals on human health. J. Toxicol. Environ. Health B Crit. Rev. 2013, 16, 321-335. [CrossRef]

11. Darbre, P.D.; Harvey, P.W. Parabens can enable hallmarks and characteristics of cancer in human breast epithelial cells: A review of the literature with reference to new exposure data and regulatory status. J. Appl. Toxicol. 2014, 34,925-938. [CrossRef]

12. Freire, C.; Molina-Molina, J.-M.; Iribarne-Durán, L.M.; Jiménez-Díaz, I.; Vela-Soria, F.; Mustieles, V.; Arrebola, J.P.; Fernández, M.F.; Artacho-Cordón, F.; Olea, N. Concentrations of bisphenol A and parabens in socks for infants and young children in Spain and their hormone-like activities. Environ. Int. 2019, 127, 592-600. [CrossRef]

13. Lange, C.; Kuch, B.; Metzger, J.W. Estrogenic activity of constituents of underarm deodorants determined by E-Screen assay. Chemosphere 2014, 108, 101-106. [CrossRef] [PubMed]

14. Kolatorova, L.; Duskova, M.; Vitku, J.; Starka, L. Prenatal exposure to bisphenols and parabens and impacts on human physiology. Physiol. Res. 2017, 66, S305-S315. [CrossRef]

15. Sandanger, T.M.; Huber, S.; Moe, M.K.; Braathen, T.; Leknes, H.; Lund, E. Plasma concentrations of parabens in postmenopausal women and self-reported use of personal care products: The NOWAC postgenome study. J. Environ. Sci. Environ. Epidemiol. 2011, 21, 595-600. [CrossRef] [PubMed]

16. Shen, X.; Liang, J.; Zheng, L.; Lv, Q.; Wang, H. Application of dispersive liquid-liquid microextraction for the preconcentration of eight parabens in real samples and their determination by high-performance liquid chromatography. J. Sep. Sci. 2017, 40, 4385-4393. [CrossRef] [PubMed]

17. Zhou, H.T.; Chen, H.C.; Ding, W.H. Accurate analysis of parabens in human urine using isotope-dilution ultrahigh-performance liquid chromatography-high resolution mass spectrometry. J. Pharm. Biomed. Anal. 2018, 150, 469-473. [CrossRef]

18. Darbre, P.D. Underarm cosmetics and breast cancer. Eur. J. Cancer Prev. 2004, 13, 153. [CrossRef]

19. Darbre, P.D.; Aljarrah, A.; Miller, W.R.; Coldham, N.G.; Sauer, M.J.; Pope, G.S. Concentrations of parabens in human breast tumours. Concentrations of parabens in human breast tumours. J. Appl. Toxicol. 2004, 24, 5-13. [CrossRef]

20. Chen, J.; Ahn, K.C.; Gee, N.A.; Gee, S.J.; Hammock, B.D.; Lasley, B.L. Antiandrogenic properties of parabens and other phenolic containing small molecules in personal care products. Toxicol. Appl. Pharm. 2007, 221, 278-284. [CrossRef]

21. Harvey, P.W.; Darbre, P. Endocrine disrupters and human health: Could oestrogenic chemicals in body care cosmetics adversely affect breast cancer incidence in women? J. Appl. Toxicol. 2004, 24, 167-176. [CrossRef]

22. Pugazhendhi, D.; Pope, G.S.; Darbre, P.D. Oestrogenic activity of p-hydroxybenzoic acid (common metabolite of paraben esters) and methylparaben in human breast cancer cell lines. J. Appl. Toxicol. 2005, 25, 301-309. [CrossRef]

23. Wang, L.; Asimakopoulos, A.G.; Kannan, K. Accumulation of 19 environmental phenolic and xenobiotic heterocyclic aromatic compounds in human adipose tissue. Environ. Int. 2015, 78, 45-50. [CrossRef]

24. Ye, X.; Bishop, A.M.; Reidy, J.A.; Needham, L.L.; Calafat, A.M. Parabens as urinary biomarkers of exposure in humans. Environ. Health Perspect. 2006, 114, 1843-1846. [CrossRef]

25. Calafat, A.M.; Ye, X.; Wong, L.Y.; Bishop, A.M.; Needham, L.L. Urinary concentrations of four parabens in the U.S. population: NHANES 2005-2006. Environ. Health Perspect. 2010, 118, 679-685. [CrossRef] [PubMed]

26. Kang, H.S.; Kyung, M.S.; Ko, A.; Park, J.H.; Hwang, M.S.; Kwon, J.E.; Suh, J.H.; Lee, H.S.; Moon, G.I.; Hong, I.G.; et al. Urinary concentrations of parabens and their association with demographic factors: A population-based cross-sectional study. Environ. Res. 2016, 146, 245-251. [CrossRef] [PubMed]

27. Wang, L.; Wu, Y.; Zhang, W.; Kannan, K. Characteristic profiles of urinary p-hydroxybenzoic acid and its esters (parabens) in children and adults from the United States and China. Environ. Sci Technol. 2013, 47, 2069-2076. [CrossRef]

28. Li, C.; Cui, X.; Chen, Y.; Liao, C. Paraben concentrations in human fingernail and its association with personal care product use. Ecotoxicol. Environ. Saf. 2020, 202, 110933. [CrossRef] [PubMed] 
29. Karwacka, A.; Zamkowska, D.; Radwan, M.; Jurewicz, J. Exposure to modern, widespread environmental endocrine disrupting chemicals and their effect on the reproductive potential of women: An overview of current epidemiological evidence. Hum. Fertil. 2019, 22, 2-25. [CrossRef]

30. Harley, K.G.; Berger, K.P.; Kogut, K.; Parra, K.; Lustig, R.H.; Greenspan, L.C.; Calafat, A.M.; Ye, X.; Eskenazi, B. Association of phthalates, parabens and phenols found in personal care products with pubertal timing in girls and boys. Hum Reprod. 2019, 34, 109-117. [CrossRef]

31. Yager, J.D.; Davidson, N.E. Estrogen carcinogenesis in breast cancer. N. Engl. J. Med. 2006, 354, 270-282. [CrossRef]

32. Barr, L.; Metaxas, G.; Harbach, C.A.; Savoy, L.A.; Darbre, P.D. Measurement of paraben concentrations in human breast tissue at serial locations across the breast from axilla to sternum. J. Appl. Toxicol. 2012, 32, 219-232. [CrossRef]

33. Sprague, B.L.; Gangnon, R.E.; Burt, V.; Trentham-Dietz, A.; Hampton, J.M.; Wellman, R.D.; Kerlikowske, K.; Miglioretti, D.L. Prevalence of mammographically dense breasts in the United States. J. Natl. Cancer Inst. 2014, 106, 255. [CrossRef] [PubMed]

34. Sprague, B.L.; Trentham-Dietz, A.; Hedman, C.J.; Wang, J.; Hemming, J.D.; Hampton, J.M.; Buist, D.S.; Bowles, E.J.; Sisney, G.S.; Burnside, E.S. Circulating serum xenoestrogens and mammographic breast density. Breast Cancer Res. 2013, 15, R45. [CrossRef] [PubMed]

35. Parada, H., Jr.; Gammon, M.D.; Ettore, H.L.; Chen, J.; Calafat, A.M.; Neugut, A.I.; Santella, R.M.; Wolff, M.S.; Teitelbaum, S.L. Urinary concentrations of environmental phenols and their associations with breast cancer incidence and mortality following breast cancer. Environ. Int. 2019, 130, 104890. [CrossRef]

36. Wu, A.H.; Franke, A.A.; Wilkens, L.R.; Tseng, C.; Conroy, S.M.; Li, Y.; Sangaramoorthy, M.; Polfus, L.M.; DeRouen, M.C.; Caberto, C.; et al. Risk of breast cancer and prediagnostic urinary excretion of bisphenol A, triclosan and parabens: The Multiethnic Cohort Study. Int. J. Cancer 2021, 149, 1426-1434. [CrossRef]

37. Golden, R.; Gandy, J.; Vollmer, G. A review of the endocrine activity of parabens and implications for potential risks to human health. Crit. Rev. Toxicol. 2005, 35, 435-458. [CrossRef] [PubMed]

38. Fuentes, N.; Silveyra, P. Estrogen receptor signaling mechanisms. Adv. Protein Chem. Struct. Biol. 2019, 116, 135-170.

39. Lee, H.R.; Kim, T.H.; Choi, K.C. Functions and physiological roles of two types of estrogen receptors, ERalpha and ERbeta, identified by estrogen receptor knockout mouse. Lab. Anim. Res. 2012, 28, 71-76. [CrossRef]

40. Arendt, L.M.; Kuperwasser, C. Form and function: How estrogen and progesterone regulate the mammary epithelial hierarchy. J. Mammary Gland. Biol. Neoplasia 2015, 20, 9-25. [CrossRef]

41. Russo, J.; Russo, I.H. Development of the human breast. Maturitas 2004, 49, 2-15. [CrossRef]

42. Hinck, L.; Silberstein, G.B. Key stages in mammary gland development: The mammary end bud as a motile organ. Breast Cancer Res. 2005, 7, 245-251. [CrossRef]

43. Silberstein, G.B. Tumour-stromal interactions. Role of the stroma in mammary development. Breast Cancer Res. 2001, 3, 218-223. [CrossRef] [PubMed]

44. Javed, A.; Lteif, A. Development of the human breast. Semin. Plast. Surg. 2013, 27, 5-12.

45. Darbre, P.D.; Byford, J.R.; Shaw, L.E.; Hall, S.; Coldham, N.G.; Pope, G.S.; Sauer, M.J. Oestrogenic activity of benzylparaben. J. Appl. Toxicol. 2003, 23, 43-51. [CrossRef] [PubMed]

46. Darbre, P.D.; Byford, J.R.; Shaw, L.E.; Horton, R.A.; Pope, G.S.; Sauer, M.J. Oestrogenic activity of isobutylparaben in vitro and in vivo. J. Appl Toxicol. 2002, 22, 219-226. [CrossRef] [PubMed]

47. Darbre, P.D.; Harvey, P.W. Paraben esters: Review of recent studies of endocrine toxicity, absorption, esterase and human exposure, and discussion of potential human health risks. J. Appl. Toxicol. 2008, 28, 561-578. [CrossRef]

48. Lemini, C.; Jaimez, R.; Avila, M.E.; Franco, Y.; Larrea, F.; Lemus, A.E. In vivo and in vitro estrogen bioactivities of alkyl parabens. Toxicol. Ind. Health 2003, 19, 69-79. [CrossRef] [PubMed]

49. Sun, L.; Yu, T.; Guo, J.; Zhang, Z.; Hu, Y.; Xiao, X.; Sun, Y.; Xiao, H.; Li, J.; Zhu, D.; et al. The estrogenicity of methylparaben and ethylparaben at doses close to the acceptable daily intake in immature Sprague-Dawley rats. Sci. Rep. 2016, 6, 25173. [CrossRef]

50. Vo, T.T.; Yoo, Y.M.; Choi, K.C.; Jeung, E.B. Potential estrogenic effect(s) of parabens at the prepubertal stage of a postnatal female rat model. Reprod. Toxicol. 2010, 29, 306-316. [CrossRef] [PubMed]

51. Wrobel, A.; Gregoraszczuk, E.L. Effects of single and repeated in vitro exposure of three forms of parabens, methyl-, butyl- and propylparabens on the proliferation and estradiol secretion in MCF-7 and MCF-10A cells. Pharm. Rep. 2013, 65, 484-493. [CrossRef]

52. Wrobel, A.M.; Gregoraszczuk, E.L. Actions of methyl-, propyl- and butylparaben on estrogen receptor-alpha and -beta and the progesterone receptor in MCF-7 cancer cells and non-cancerous MCF-10A cells. Toxicol. Lett. 2014, 230, 375-381. [CrossRef]

53. Dall, G.V.; Hawthorne, S.; Seyed-Razavi, Y.; Vieusseux, J.; Wu, W.; Gustafsson, J.A.; Byrne, D.; Murphy, L.; Risbridger, G.P.; Britt, K.L. Estrogen receptor subtypes dictate the proliferative nature of the mammary gland. J. Endocrinol. 2018, 237, 323-336. [CrossRef]

54. Treeck, O.; Lattrich, C.; Springwald, A.; Ortmann, O. Estrogen receptor beta exerts growth-inhibitory effects on human mammary epithelial cells. Breast Cancer Res. Treat. 2010, 120, 557-565. [CrossRef]

55. Kunc, M.; Biernat, W.; Senkus-Konefka, E. Estrogen receptor-negative progesterone receptor-positive breast cancer-"Nobody's land" or just an artifact? Cancer Treat. Rev. 2018, 67, 78-87. [CrossRef]

56. Lanari, C.; Molinolo, A.A. Progesterone receptors-Animal models and cell signalling in breast cancer. Diverse activation pathways for the progesterone receptor: Possible implications for breast biology and cancer. Breast Cancer Res. 2002, 4, 240-243. [CrossRef] 
57. Wrobel, A.M.; Gregoraszczuk, E.L. Differential effect of methyl-, butyl- and propylparaben and 17beta-estradiol on selected cell cycle and apoptosis gene and protein expression in MCF-7 breast cancer cells and MCF-10A non-malignant cells. J. Appl. Toxicol. 2014, 34, 1041-1050. [CrossRef] [PubMed]

58. Terasaka, S.; Inoue, A.; Tanji, M.; Kiyama, R. Expression profiling of estrogen-responsive genes in breast cancer cells treated with alkylphenols, chlorinated phenols, parabens, or bis- and benzoylphenols for evaluation of estrogenic activity. Toxicol. Lett. 2006, 163, 130-141. [CrossRef]

59. Pugazhendhi, D.; Sadler, A.J.; Darbre, P.D. Comparison of the global gene expression profiles produced by methylparaben, n-butylparaben and 17beta-oestradiol in MCF7 human breast cancer cells. J. Appl. Toxicol. 2007, 27, 67-77. [CrossRef] [PubMed]

60. Gopalakrishnan, K.; Teitelbaum, S.L.; Lambertini, L.; Wetmur, J.; Manservisi, F.; Falcioni, L.; Panzacchi, S.; Belpoggi, F.; Chen, J Changes in mammary histology and transcriptome profiles by low-dose exposure to environmental phenols at critical windows of development. Environ. Res. 2017, 152, 233-243. [CrossRef] [PubMed]

61. Lillo, M.A.; Nichols, C.; Perry, C.; Runke, S.; Krutilina, R.; Seagroves, T.N.; Miranda-Carboni, G.A.; Krum, S.A. Methylparaben stimulates tumor initiating cells in ER+ breast cancer models. J. Appl. Toxicol. 2017, 37, 417-425. [CrossRef]

62. Zimmerman, M.A.; Budish, R.A.; Kashyap, S.; Lindsey, S.H. GPER-novel membrane oestrogen receptor. Clin. Sci. 2016, 130, 1005-1016. [CrossRef]

63. Xu, S.; Yu, S.; Dong, D.; Lee, L.T.O. G Protein-Coupled Estrogen Receptor: A Potential Therapeutic Target in Cancer. Front. Endocrinol. 2019, 10, 725. [CrossRef] [PubMed]

64. Jung, J. Role of G Protein-Coupled Estrogen Receptor in Cancer Progression. Toxicol. Res. 2019, 35, 209-214. [CrossRef] [PubMed]

65. Wrobel, A.M.; Gregoraszczuk, E.L. Action of methyl-, propyl- and butylparaben on GPR30 gene and protein expression, cAMP levels and activation of ERK1/2 and PI3K/Akt signaling pathways in MCF-7 breast cancer cells and MCF-10A non-transformed breast epithelial cells. Toxicol. Lett. 2015, 238, 110-116. [CrossRef] [PubMed]

66. Guan, B.Z.; Yan, R.L.; Huang, J.W.; Li, F.L.; Zhong, Y.X.; Chen, Y.; Liu, F.N.; Hu, B.; Huang, S.B.; Yin, L.H. Activation of G protein coupled estrogen receptor (GPER) promotes the migration of renal cell carcinoma via the PI3K/AKT/MMP-9 signals. Cell Adh Migr. 2018, 12, 109-117. [CrossRef] [PubMed]

67. Yan, Y.; Liu, H.; Wen, H.; Jiang, X.; Cao, X.; Zhang, G.; Liu, G. The novel estrogen receptor GPER regulates the migration and invasion of ovarian cancer cells. Mol. Cell. Biochem. 2013, 378, 1-7. [CrossRef]

68. Hsu, L.H.; Chu, N.M.; Lin, Y.F.; Kao, S.H. G-Protein Coupled Estrogen Receptor in Breast Cancer. Int. J. Mol. Sci. 2019, 20, 306. [CrossRef]

69. Girgert, R.; Emons, G.; Grundker, C. Estrogen Signaling in ERalpha-Negative Breast Cancer: ERbeta and GPER. Front Endocrinol 2018, 9, 781. [CrossRef]

70. Marchese, S.; Silva, E. Disruption of 3D MCF-12A breast cell cultures by estrogens-an in vitro model for ER-mediated changes indicative of hormonal carcinogenesis. PLOS ONE 2012, 7, e45767.

71. Périan, S.; Cerutti, C.; Forcet, C.; Tribollet, V.; Vanacker, J. A Cell-Based Method to Detect Agonist and Antagonist Activities of Endocrine-Disrupting Chemicals on GPER. Front. Endocrinol. 2020, 11, 547. [CrossRef]

72. Sasano, H.; Miki, Y.; Nagasaki, S.; Suzuki, T. In situ estrogen production and its regulation in human breast carcinoma: From endocrinology to intracrinology. Pathol. Int. 2009, 59, 777-789. [CrossRef]

73. Zhao, H.; Zhou, L.; Shangguan, A.J.; Bulun, S.E. Aromatase expression and regulation in breast and endometrial cancer. J. Mol. Endocrinol. 2016, 57, R19-R33. [CrossRef] [PubMed]

74. Van Meeuwen, J.A.; Van Son, O.; Piersma, A.H.; de Jong, P.C.; Van den Berg, M. Aromatase inhibiting and combined estrogenic effects of parabens and estrogenic effects of other additives in cosmetics. Toxicol. Appl. Pharm. 2008, 230, 372-382. [CrossRef] [PubMed]

75. Stocco, C. Tissue physiology and pathology of aromatase. Steroids 2012, 77, 27-35. [CrossRef] [PubMed]

76. Harada, N.; Utsumi, T.; Takagi, Y. Tissue-specific expression of the human aromatase cytochrome P-450 gene by alternative use of multiple exons 1 and promoters, and switching of tissue-specific exons 1 in carcinogenesis. Proc. Natl. Acad. Sci. USA 1993, 90, 11312-11316. [CrossRef] [PubMed]

77. Hilborn, E.; Stal, O.; Jansson, A. Estrogen and androgen-converting enzymes 17beta-hydroxysteroid dehydrogenase and their involvement in cancer: With a special focus on 17beta-hydroxysteroid dehydrogenase type 1, 2, and breast cancer. Oncotarget 2017, 8, 30552-30562. [CrossRef]

78. Gunnarsson, C.; Hellqvist, E.; Stal, O. 17beta-Hydroxysteroid dehydrogenases involved in local oestrogen synthesis have prognostic significance in breast cancer. Br. J. Cancer 2005, 92, 547-552. [CrossRef]

79. Gunnarsson, C.; Olsson, B.M.; Stal, O. Abnormal expression of 17beta-hydroxysteroid dehydrogenases in breast cancer predicts late recurrence. Cancer Res. 2001, 61, 8448-8451.

80. Yazawa, T.; Imamichi, Y.; Uwada, J.; Sekiguchi, T.; Mikami, D.; Kitano, T.; Sato, T.; Nemoto, T.; Nagata, S.; Khan, R.I.; et al. Evaluation of 17 beta-hydroxysteroid dehydrogenase activity using androgen receptor-mediated transactivation. J. Steroid Biochem. Mol. Biol. 2020, 196, 105493. [CrossRef]

81. Engeli, R.T.; Rohrer, S.R.; Vuorinen, A.; Herdlinger, S.; Kaserer, T.; Leugger, S.; Schuster, D. Odermatt, AInterference of Paraben Compounds with Estrogen Metabolism by Inhibition of 17beta-Hydroxysteroid Dehydrogenases. Int. J. Mol. Sci. 2017, 18, 2007. [CrossRef]

82. Miller, D.; Wheals, B.B.; Beresford, N.; Sumpter, J.P. Estrogenic activity of phenolic additives determined by an in vitro yeast bioassay. Environ. Health Perspect. 2001, 109, 133-138. [CrossRef]

83. Berrino, F.; Pasanisi, P.; Bellati, C.; Venturelli, E.; Krogh, V.; Mastroianni, A.; Berselli, E.; Muti, P.; Secreto, G. Serum testosterone levels and breast cancer recurrence. Int. J. Cancer 2005, 113, 499-502. [CrossRef] 
84. Giovannelli, P.; Di Donato, M.; Auricchio, F.; Castoria, G.; Migliaccio, A. Androgens Induce Invasiveness of Triple Negative Breast Cancer Cells Through AR/Src/PI3-K Complex Assembly. Sci. Rep. 2019, 9, 4490. [CrossRef]

85. Giovannelli, P.; Di Donato, M.; Galasso, G.; Di Zazzo, E.; Bilancio, A.; Migliaccio, A. The Androgen Receptor in Breast Cancer. Front. Endocrinol. 2018, 9, 492. [CrossRef]

86. Venturelli, E.; Orenti, A.; Fabricio, A.S.C.; Garrone, G.; Agresti, R.; Paolini, B.; Bonini, C.; Gion, M.; Berrino, F.; Desmedt, C.; et al. Observational study on the prognostic value of testosterone and adiposity in postmenopausal estrogen receptor positive breast cancer patients. BMC Cancer 2018, 18, 651 .

87. Doane, A.S.; Danso, M.; Lal, P.; Donaton, M.; Zhang, L.; Hudis, C.; Gerald, W.L. An estrogen receptor-negative breast cancer subset characterized by a hormonally regulated transcriptional program and response to androgen. Oncogene 2006, 25, 3994-4008. [CrossRef]

88. Liao, Y.; Xia, X.; Liu, N.; Cai, J.; Guo, Z.; Li, Y.; Jiang, L.; Dou, Q.P.; Tang, D.; Huang, H.; et al. Growth arrest and apoptosis induction in androgen receptor-positive human breast cancer cells by inhibition of USP14-mediated androgen receptor deubiquitination. Oncogene 2018, 37, 1896-1910. [CrossRef]

89. Ni, M.; Chen, Y.; Lim, E.; Wimberly, H.; Bailey, S.T.; Imai, Y.; Rimm, D.L.; Liu, X.S.; Brown, M. Targeting androgen receptor in estrogen receptor-negative breast cancer. Cancer Cell 2011, 20, 119-131. [CrossRef] [PubMed]

90. Satoh, K.; Nonaka, R.; Ohyama, K.; Nagai, F. Androgenic and Antiandrogenic Effects ofAlkylphenols and Parabens AssessedUsing the Reporter Gene Assay withStably Transfected CHO-K1 Cells(AR-EcoScreen System). J. Health Sci. 2005, 51, 12.

91. Kolsek, K.; Gobec, M.; Rascan, I.M.; Dolenc, M.S. Screening of bisphenol A, triclosan and paraben analogues as modulators of the glucocorticoid and androgen receptor activities. Toxicol. Vitr. 2015, 29, 8-15. [CrossRef] [PubMed]

92. Pelch, K.E.; Li, Y.; Perera, L.; Thayer, K.A.; Korach, K.S. Characterization of Estrogenic and Androgenic Activities for Bisphenol A-like Chemicals (BPs): In Vitro Estrogen and Androgen Receptors Transcriptional Activation, Gene Regulation, and Binding Profiles. Toxicol. Sci. 2019, 172, 23-37. [CrossRef]

93. Hu, P.; Chen, X.; Whitener, R.J.; Boder, E.T.; Jones, J.O.; Porollo, A.; Chen, J.; Zhao, L. Effects of parabens on adipocyte differentiation. Toxicol. Sci. 2013, 131, 56-70. [CrossRef] [PubMed]

94. Iqbal, N.; Iqbal, N. Human Epidermal Growth Factor Receptor 2 (HER2) in Cancers: Overexpression and Therapeutic Implications. Mol. Biol. Int. 2014, 2014, 852748. [CrossRef]

95. Liu, P.; Cheng, H.; Roberts, T.M.; Zhao, J.J. Targeting the phosphoinositide 3-kinase pathway in cancer. Nat. Rev. Drug Discov. 2009, 8, 627-644. [CrossRef] [PubMed]

96. Bader, A.G.; Kang, S.; Zhao, L.; Vogt, P.K. Oncogenic PI3K deregulates transcription and translation. Nat. Rev. Cancer 2005, 5, 921-929. [CrossRef]

97. Davoli, A.; Hocevar, B.A.; Brown, T.L. Progression and treatment of HER2-positive breast cancer. Cancer Chemother. Pharm. 2010, 65, 611-623. [CrossRef]

98. Vasan, N.; Toska, E.; Scaltriti, M. Overview of the relevance of PI3K pathway in HR-positive breast cancer. Ann. Oncol. 2019, 30, x3-x11. [CrossRef] [PubMed]

99. Pan, S.; Yuan, C.; Tagmount, A.; Rudel, R.A.; Ackerman, J.M.; Yaswen, P.; Vulpe, C.D.; Leitman, D.C. Parabens and Human Epidermal Growth Factor Receptor Ligand Cross-Talk in Breast Cancer Cells. Environ. Health Perspect. 2016, 124, 563-569. [CrossRef] [PubMed]

100. Khanna, S.; Darbre, P.D. Parabens enable suspension growth of MCF-10A immortalized, non-transformed human breast epithelial cells. J. Appl. Toxicol. 2013, 33, 378-382. [CrossRef]

101. Fedele, M.; Cerchia, L.; Chiappetta, G. The Epithelial-to-Mesenchymal Transition in Breast Cancer: Focus on Basal-Like Carcinomas. Cancers 2017, 9, 134. [CrossRef]

102. Savci-Heijink, C.D.; Halfwerk, H.; Hooijer, G.K.J.; Koster, J.; Horlings, H.M.; Meijer, S.L.; van de Vijver, M. Epithelial-tomesenchymal transition status of primary breast carcinomas and its correlation with metastatic behavior. Breast Cancer Res. Treat. 2019, 174, 649-659. [CrossRef]

103. Drasin, D.J.; Robin, T.P.; Ford, H.L. Breast cancer epithelial-to-mesenchymal transition: Examining the functional consequences of plasticity. Breast Cancer Res. 2011, 13, 226. [CrossRef] [PubMed]

104. Khanna, S.; Dash, P.R.; Darbre, P.D. Exposure to parabens at the concentration of maximal proliferative response increases migratory and invasive activity of human breast cancer cells in vitro. J. Appl. Toxicol. 2014, 34, 1051-1059. [CrossRef] [PubMed] 